\title{
How Blood Group Relates with Dandruff
}

\author{
Muhammad Imran Qadir and Usama Razzaq* \\ Institute of Molecular Biology and Biotechnology, Bahauddin Zakariya University, Pakistan
}

Submission: May 03, 2019 ; Published: May 07, 2019

*Corresponding author: Usama Razzaq, Institute of Molecular Biology and Biotechnology, Bahauddin Zakariya University, Pakistan

\begin{abstract}
The major objective of this article was to design a connection between blood grouping and Dandruff in hair cells. ABO Blood grouping is a system of classifying blood groups on the basis of presence or absence of antigens A, B, or both and antibodies against these antigens. Based on Rhesus factor, blood group is distinguish on Rh factor presence or absence on cell surface. Presence on cell surface of Rh factor (D antigen) regarded as $\mathrm{Rh}+$ and absence regarded as Rh- blood group. This article also ventilates about Dandruff, its causes and its treatments. Samples of 144 subjects were taken from their consents. These subjects were the students of Bahauddin Zakariya University Multan, Pakistan. It was concluded that $\mathrm{B}+$ and $\mathrm{O}+$ blood groups have maximum threat of dandruff while B- blood group has minimum threat.
\end{abstract}

Keywords: Dandruff in hairs; Whitening dry scalp; Shampoos and blood group

\section{Introduction}

ABO Blood group is the classification of blood based on the presence and absence of Antigens A, B or both and Antibodies against these antigens. In 1901, ABO blood group system was discovered by Karl Landsteiner. $\mathrm{ABO}$ blood group system has the

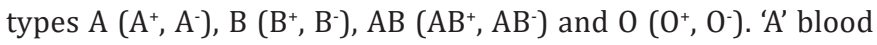
group type is indicated on the presence of $A$ antigen and anti- $B$ antibodies. 'B' blood group has B antigen and anti-A antibodies. While 'AB' blood group has no antibodies and has both $\mathrm{A}$ and $\mathrm{B}$ antigens. ' $\mathrm{O}$ ' blood group has no antigens and has anti-A and anti-B antibodies. $\mathrm{O}^{+}$and $\mathrm{A}^{+}$blood groups are most abundant in the population while $\mathrm{B}^{-}, \mathrm{AB}^{+}$and $\mathrm{AB}^{-}$blood groups are the rare one in the world population. $\mathrm{A}^{+}$blood group person can denote blood to $\mathrm{A}^{+}$and to $\mathrm{AB}^{+}$blood group person and can receive blood from $\mathrm{A}^{+}, \mathrm{A}^{-}, \mathrm{O}^{+}$and from $\mathrm{O}$ - blood group person. $\mathrm{O}^{+}$blood group person can denote blood to $\mathrm{O}^{+}, \mathrm{A}^{+}, \mathrm{B}^{+}$and to $\mathrm{AB}^{+}$blood group person while he can receive blood from $\mathrm{O}^{+}$and from 0 - person. $\mathrm{B}^{+}$blood group person denote blood to $\mathrm{B}^{+}$and to $\mathrm{AB}^{+}$person and receive blood from $\mathrm{B}^{+}, \mathrm{B}^{-}, \mathrm{O}^{+}$and from $\mathrm{O}^{-}$person. $\mathrm{AB}^{+}$blood group person denote blood to $\mathrm{AB}^{+}$and receive blood from everyone [1]. Another Blood group type is Rh Rhesus blood grouping system. This Rhesus factor was discovered in 1937 by Karl Landsteiner and Alexander S. Weiner. This blood group type has 49 defined antigens of which 5 important antigens D, C, c, E and e are well known. Status of Rh factor of an individual is normally described with a positive $\mathrm{Rh}^{+}$and negative $\mathrm{Rh}^{-}$suffix in accordance with $\mathrm{ABO}$ blood grouping. As $\mathrm{A}^{+}$blood group has $\mathrm{A}$ antigen along with
$\mathrm{Rh}(\mathrm{D})$ factor presence while $\mathrm{A}^{-}$blood group has A antigen and it lack $\mathrm{Rh}(\mathrm{D})$ factor presence [2].

Dandruff is a chronic scalp skin cells condition and marked by the flaking of the skin cells, which falls off as white dots while combing and shaking head making embarrassment for the person. It results in social or self-esteem problems. Dandruff usually starts from puberty frequently in 50\% adults and its causes may be genetic and environmental factors or not shampooing daily or even a week. Its main cause is a fungus malassezia lives on the scalp of the adults. It causes irritation and more skin cells to grow. The extra cells die and tear off and appear white dots regarded as dandruff. Symptoms of dandruff include itching and flaking of dead skin cells. Mild cases of dandruff need shampooing daily and its severe condition require medical attention. Dandruff can be treated by using shampoos on wet hairs daily, anti-dandruff shampoos may be Head and Shoulders, Selsun Blue and Nizoral A-D anti-dandruff shampoo. Other treatment involves use of lemon juice. Lemon's acidity helps to balance the $\mathrm{pH}$ of scalp. Coconut oil usage improves skin hydration, Aloe Vera applied on wet hairs along with a shampoo can decrease dandruff symptoms because Aloe Vera has anti-bacterial and anti-fungal properties. Another treatment is the use of Apple Cider Vinegar which removes dead skin cells from the scalp and also balance the $\mathrm{pH}$ of scalp. Stress is also a factor playing vital role in dandruff growth as stress weakens the immune system and decrease the body's capacity to fight off 
infections [3]. The main purpose of this article was to design a connection between blood grouping and Dandruff.

\section{Materials and Methods}

\section{Method}

Blood group identification principle is based on Agglutination reaction. Needle, cotton piece, a antiseptic agent, a slide and antibodies are required in the apparatus. Firstly, hands of patient are cleaned by a specific antiseptic agent and then blood sample is taken from the finger of the person by pricking with a needle. 3 drops of blood is taken on a slide, then mixed a blood group reagent i.e. antibodies against type A and B. When blood having one or more antigen exposed to corresponding antibodies, they interact with each other to form a clump or agglutination. The sample in which red blood cells stick together is the blood group of the person [4].

\section{Statistical analysis}

Microsoft EXCEL is used for statistical analysis. Data of 144 students can be calculated on EXCEL worksheet [5].

\section{Project designing}

We took samples of 144 different subjects of having or not having dandruff in accordance with their blood groups with their consents. These students include Males and Females, their data then be given a tubular form. These subjects were the students of Bahauddin Zakariya University Multan, Pakistan [6].

\section{Results and Discussion}

How Blood Group relates with Dandruff is given in following Table 1. According to data in tubular form, (yes or no for having or not having dandruff) $\mathrm{A}^{+}$Blood group Female have more percentage of dandruff then Males. Similarly, A- Females also have greater percentage of dandruff then males. This result is same for all blood groups as females have more dandruff as they have long hairs. Long hairs need more care. An important Advancement has been given by Questionnaire based studies in Recent Researches. This article has been also published by S Ranganathan in 2010 as he studied on Dandruff- the most commercially exploited skin disease [7-10].
Table 1: How Blood Group relates with Dandruff.

\begin{tabular}{|c|c|c|c|c|}
\hline $\begin{array}{c}\text { Blood } \\
\text { Group }\end{array}$ & Male Yes \% & Male No \% & $\begin{array}{c}\text { Female Yes } \\
\%\end{array}$ & $\begin{array}{c}\text { Female } \\
\text { No \% }\end{array}$ \\
\hline $\mathrm{A}^{+}$ & 20 & 28 & 48 & 4 \\
\hline $\mathrm{A}^{-}$ & 16.9 & 33.1 & 50 & 0 \\
\hline $\mathrm{B}^{+}$ & 21 & 18 & 30.1 & 30 \\
\hline $\mathrm{B}^{-}$ & 20 & 0 & 40.1 & 39.9 \\
\hline $\mathrm{AB}^{+}$ & 16.7 & 26 & 26 & 30.01 \\
\hline $\mathrm{AB}^{-}$ & 16.5 & 16.5 & 67 & 0 \\
\hline $\mathrm{O}^{+}$ & 18 & 24.025 & 33 & 24.02 \\
\hline $\mathrm{O}^{-}$ & 16.06 & 16.05 & 50 & 16.01 \\
\hline
\end{tabular}

\section{Conclusion}

$\mathrm{B}^{+}$and $\mathrm{O}^{+}$blood group females have more percentage of dandruff while B- people has minimum dandruff.

\section{References}

1. Qadir MI, Malik SA (2010) Comparison of alterations in red blood cell count and alterations in hemoglobin concentration in patients suffering from rectal carcinoma undergoing 5-fluorouracil and folic acid therapy. Pharmacology online 3: 240-243.

2. Qadir MI, Noor A (2018) Anemias. Rare \& Uncommon Diseases. Cambridge Scholars Publishing. Newcastle, England, UK.

3. Qadir MI, Javid A (2018) Awareness about Crohn's Disease in biotechnology students. GloAdv Res J Med Medical Sci 7(3): 062-064.

4. Qadir MI, Saleem A (2018) Awareness about ischemic heart disease in university biotechnology students. GloAdv Res J Med Medical Sci 7(3): 059-061.

5. Qadir MI, Ishfaq S (2018) Awareness about hypertension in biology students. Int J Mod Pharma Res 7(2): 08-10.

6. Qadir MI, Mehwish (2018) Awareness about psoriasis disease. Int J Mod Pharma Res 7(2): 17-18.

7. Qadir MI, Shahzad R (2018) Awareness about obesity in postgraduate students of biotechnology. Int J Mod Pharma Res 7(2): 14-16.

8. Qadir MI, Rizvi M (2018) Awareness about thalassemia in post graduate students. MOJ Lymphology \& Phlebology 2(1): 14-16.

9. Qadir MI, Ghalia BA (2018) Awareness survey about colorectal cancer in students of M. Phil Biotechnology at Bahauddin Zakariya University, Multan, Pakistan. Nov Appro in Can Study 1(3): NACS.000514.

10. Qadir MI, Saba G (2018) Awareness about intestinal cancer in university student. Nov Appro in Can Study 1(3): NACS.000515. 
(C) Commons Attribution 4.0 License
Your next submission with Juniper Publishers will reach you the below assets

- Quality Editorial service

- Swift Peer Review

- Reprints availability

- E-prints Service

- Manuscript Podcast for convenient understanding

- Global attainment for your research

- Manuscript accessibility in different formats ( Pdf, E-pub, Full Text, Audio)

- Unceasing customer service

Track the below URL for one-step submission https://juniperpublishers.com/online-submission.php 